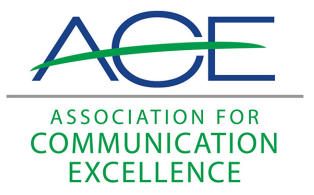

Journal of Applied Communications

\title{
"Extension's Partnership with the Future"; "To Educate a People"; "The Extension Organization of the Future"; Prairie Schooner Nebraska: The Individual Voice.
}

Jim Shaner

Jim King

Follow this and additional works at: https://newprairiepress.org/jac (c) (†) (-)

This work is licensed under a Creative Commons Attribution-Noncommercial-Share Alike 4.0 License.

\section{Recommended Citation}

Shaner, Jim and King, Jim (1987) "'Extension's Partnership with the Future"; "To Educate a People"; "The Extension Organization of the Future"; Prairie Schooner Nebraska: The Individual Voice.," Journal of Applied Communications: Vol. 70: Iss. 2. https://doi.org/10.4148/1051-0834.1583

This Review is brought to you for free and open access by New Prairie Press. It has been accepted for inclusion in Journal of Applied Communications by an authorized administrator of New Prairie Press. For more information, please contact cads@k-state.edu. 
"Extension's Partnership with the Future"; "To Educate a People"; "The Extension Organization of the Future"; Prairie Schooner Nebraska: The Individual Voice.

\begin{abstract}
Reviews of "Extension's Partnership with the Future," by Michael Quinn Patton; "To Educate a People"; "The Extension Organization of the Future"; Prairie Schooner Nebraska: The Individual Voice.
\end{abstract}




\section{Reviews}

The Journal of Extension features a new section that should interest ACE readers. "Futures, " by Michael Quinn Patton, University of Minnesota-St. Paul, examines the changing role and scope of Extension as an information delivery system in the computer age. Patton, the Journal's future editor, examines the changes in American society that he thinks are influencing the changes most of us see in Extension today. In mapping the coming impact of change, he begins with the growing influence of two important information channels.

\section{"Extension's Partnership with the Future." Michael Quinn Pat- ton in Journal of Extension. Fall, 1986, pp. 15-17.}

In this offering, like most of us, Patton sees individuals as having much greater access to information, as television becomes even more pervasive-and as the adoption process for microcomputers follows the same pattern that, earlier, we saw for television.

The combined impact of such ready access may increase people's feelings of isolation, eventually affecting Extension's ability to form the interagency partnerships that have brought it some fame.

Patton sees Extension's role changing from that of active participant to "nurturing" facilitator. That change will be needed, he reasons, to counter a trend toward "individual isolation, community atomization, organizational autonomy, and interagency conflict,", which stems, Patton says, from gathering information, remotely, in homes and offices isolated from others.

Consequently, for a vast network of information-sharing to work, he reasons, a trusted institution must sit at its center, facilitating and coordinating that sharing.

"Ironically, the increased importance of creating and facilitating partnerships among others," Patton reasons, "is likely to reduce Extension's ability to enter into those partnerships" as a full participant.

Yet he still sees Extension as developing as facilitator more than as a leader. So he concludes we will be replacing Extension's leadership with skills in mediation, its commitment to goals with neutrality, and its willingness to share resources with skill in mobilizing others to fully use their own resources collectively.

Microcomputers may become an even more useful tool in Extension work. Patton describes a consensus-building function, served 
by connecting a microcomputer to those in homes and offices. It would tabulate everyone's "vote" as people key-in their opinions. The Extension facilitator, monitoring the screen, looks for patterns and potential consensus items to promote "collective decision making without people coming together in a group."

"With its university base and roots in local communities, Extension" already "is uniquely poised to play the role of partnership creator, mediator, broker, and facilitator," Patton writes. He notes that it works between government, the public and private nonprofit sectors, and the private business sector. Consequently, "new communications and problem-solving technologies will be part of Extension's partnership-building methods" in the future.

\section{“To Educate a People," Winter, 1986, pp. 21-22.}

Here, Patton sees building a more effective relationship between Cooperative Extension and continuing education units as vital to Extension's future. The Minnesota professor depicts continuing education programs as using a classroom approach to outreach that involves all university disciplines. In contrast, Extension, typically, only involves the traditional disciplines of agriculture, home economics, youth, and (rural) community development, but delivers its education in an informal way that also is targeted directly to meeting people's needs.

Consequently, Patton sees Extension's opportunity as lying in a marriage of the two approaches-one that is already practiced in programs at the universities of Wisconsin, Minnesota, Missouri, and others.

Patton sees competition from continuing education units across every campus to Extension's establishing itself as "the centerpiece of university outreach."

Then, Patton lists Extension's unique qualifications for that role:

1. Its community-based program development is "unique to universities."

2. "Extension professionals know more about informal, adult education than any other group on campus." (Faculty in colleges of education, presumably, would argue this point.)

3. Extension's county-based network is unique among universities in linking the university to the people.

4. The Extension and the experiment station networks have the know-how to conduct and disseminate applied research "in all areas of knowledge" (another arguable point).

5. And, finally, Extension already has a commitment to educate all the people of the state and is unique, on campuses, in applying those land-grant values to the educational process. 
Shaner and King: "Extension's Partnership with the Future"; "To Educate a People" "The Extension Organization of the Future," Spring, 1987, pp. 22-24.

Michael Quinn Patton moves beyond the financial crisis of Extension to the forces which shape the new information age.

First, he sets the scene by contrasting the organizational approaches effective during the Industrial Age with those which may be labelled "Information Age."

Industrial Age organizations are designed to accomplish specific goals and to monitor progress, following a linear input-output model of cause and effect. Accountability is focused upon individuals accomplishing specific and local goals in order for the organization to accomplish its goals through the aggregation of roles, responsibilities and objectives.

In contrast, organizations in the information age apply team approaches, with flexible responsibilities and accountabilities.

During this transition, Extension specialists are caught in a paradox. Specific job descriptions, an earmark of the industrial age, conflict with the flexible positions needed to solve wholistic problems, a touchstone of the approach used in the information age. Concrete, annual plans of work conflict with the varying tasks and contributions needed from a single individual participating in several teams. And individual accountability conflicts with the team approach.

Patton offers a table of 12 characteristics that contrast the Extension organization of an industrial age with that of the information age. Many have been noted before, but Patton provides a compelling explanation for the breadth and scope of the change now underway.

Jim Shaner

University of Missouri-Columbia

Prairie Schooner Nebraska: The Individual Voice. Vol. 60, No. 2, Summer, 1986 (142 pages). Available from: Prairie Schooner, 201 Andrews Hall, University of Nebraska, Lincoln, NE. 68588 (\$3.25).

Ideas are the soul of the communication process. And as communicators we need the constant stimulation of good literature to keep current in our content and techniques. 
In this time of agricultural economic crisis and expanding biological opportunity, there appears a tremendous source to reconnect us to our roots: the Summer, 1986, edition of the Prairie Schooner. It is a regional literary quarterly which brings its readers the "spirit of pioneer adventure and action and endurance that could have some significance." Last summer the Prairie Schooner, one of the most highly rated literary magazines of its type in the United States, focused on Nebraska and the rural sector with a spectacular collection of essays, interviews, journals, poetry and fiction.

Authors include working Nebraskan women and men, University of Nebraska faculty, the publisher of The Polk Progress newspaper ("Slower is Better'), transplanted Nebraskans (to Cornell, Alaska, Las Cruces) and many other hearty contributors.

The titles of these poems in the edition give you an indication of the quarterly's scope: "Farm Auction," "Evening Chores," "For the Barley Sower," "August in Nebraska," "Miracle at Stink Creek," “Quilt Poem \#1," "A Widow's Grief, 1897,", "Down on the Farm in Heaven, Nebraska," "Airing Out," and "I-80 with Charles Darwin."

Interviews include a woman who lived in a sod house and a man who recalled unionism on the urban prairie in the ' 30 s and ' 40 s. And journal entries come from a "marginal man" in the $1860 \mathrm{~s}$ (neither full-blooded Indian nor white) and from a French woman living on the Crow Creek Indian Reservation in 1899.

There's plenty of backgrounding material for agricultural communications as well as fodder for new projects from the Prairie Schooner. But I'll leave you with Mrs. Heft in small town, rural Nebraska, who..."'Stops when the Union Pacific passed, ..... smelling air as crisp as Oxydol, looking up at stars the Pawnee Indians looked at, hearing the low harmonica of big rigs on the highway, in the town she knows like the palm of her hand, in the country she knows by heart." 